\title{
LAYARD'S DESCRIPTIONS OF ROOMS IN THE SOUTHWEST PALACE AT NINEVEH
}

\author{
By JOHN MALCOLM RUSSELL
}

The "Palace without Rival" at Nineveh, built by the Neo-Assyrian king Sennacherib (704-681 BC), was excavated by Austen Henry Layard in two campaigns in the mid-nineteenth century. The results of the first campaign, in May and June 1847, were published in considerable detail in Nineveh and its Remains (1849). The results of the second, from October 1849 to April 1851, were reported in less detail in Discoveries in the Ruins of Nineveh and Babylon (1853).

Among the Layard Papers in the British Library are the unpublished notes that served as the basis for the published reports. The notes for the first campaign, in Add. Ms. 39076, fol. 43-54, are in the form of a full narrative account, penned in Layard's best hand. The notes for the second campaign are preserved in two versions. The earlier is a rough incomplete account in two of Layard's pocket notebooks. The first covers the period 17 October to 13 November 1850 (Add. Ms. 39089C, fol. 612) and includes notes on Rooms $E, I$ to $S, V, Y$, and DD (the latter mistakenly labelled "FF" in the notebook). The second notebook, which covers 5 December 1850 to 26 April 1851 (Add. Ms. $39089 \mathrm{E}$, fol. $29 \mathrm{v}-34 \mathrm{v}$ ), records Rooms GG, II to LL, part of MM (mislabelled "PP"), SS to WW, YY, AAA, and DDD to OOO. These are very rough field notes, sketchy and almost illegible. The later set of notes from the second campaign (Add. Ms. 39077, fol. 75r-79v) is more complete, covering Rooms I to OOO, all of the rooms excavated during that campaign. This account, which must have been compiled after the close of the excavation, is apparently based in part on the notes in the pocket notebooks. It includes a number of additional rooms, however - T, U, W, X, Z, AA, $\mathrm{BB}, \mathrm{CC}, \mathrm{EE}, \mathrm{FF}, \mathrm{MM}$ (full description), NN to RR, XX, BBB, and CCC - and therefore it may also have drawn on field notes that have not yet been identified. Unlike the field notes, it is written fairly legibly and in complete sentences, in the same manner as the report of the first campaign.

These two long reports together constitute the most complete known narrative account of Layard's finds in Sennacherib's palace. Since they include much information that is not in Layard's published accounts, they are basic source material, both for identifying the unlabelled original drawings of reliefs from Sennacherib's palace, and for reconstructing the original appearance of the palace. Because they are such important documents for an understanding of the palace, they are quoted here in full.

A few preliminary comments may help to place these accounts in context. First, Layard's system of designating rooms in Sennacherib's palace changed between his first and second publications. In Nineveh and Its Remains, Layard referred to each room by a letter, as he had done also with Assurnasirpal II's palace at Nimrud. He continued to employ this system in his notes from the second campaign, but evidently found the system too cumbersome and used Roman numerals instead when he published this material in Nineveh and Babylon. This was true also for Layard's plans of Sennacherib's palace, in which letter designations were used in the plan of the 1847 season (Fig. 1), and continued to be used in his field plan of the 1849-51 campaign (Fig. 2), but were replaced by Roman numerals in the final published plan (Fig. 3). All three of these plans are included here for convenience of reference. Note that in the field plan, several rooms $-\mathrm{T}, \mathrm{XX}$, GGG, HHH, and III - are shown out of place, presumably because Layard's sheet of paper was not large enough to accommodate them in their actual position.

In the transcriptions that follow, Layard's text is reproduced as literally as I could manage, using his own capitalization and punctuation. ${ }^{1}$ The room and door designations from Layard's final published plan are included in square brackets. In the comments that follow each entry, attention is drawn to those features that differ from Layard's published accounts. At the end is a concordance of Roman numeral room designations in the published accounts and the letter designations in the manuscripts. I am very grateful to Dominique Collon ${ }^{2}$ for answering questions about the content of

\footnotetext{
${ }^{1}$ However, abbreviated words have been rendered in full, the spelling has been corrected where faulty, and some

${ }^{2}$ Personal communications, letters of 19 August 1993 and 22
June 1994 . inconsistencies of style have been eliminated.
} Iraq LVII (1995) 


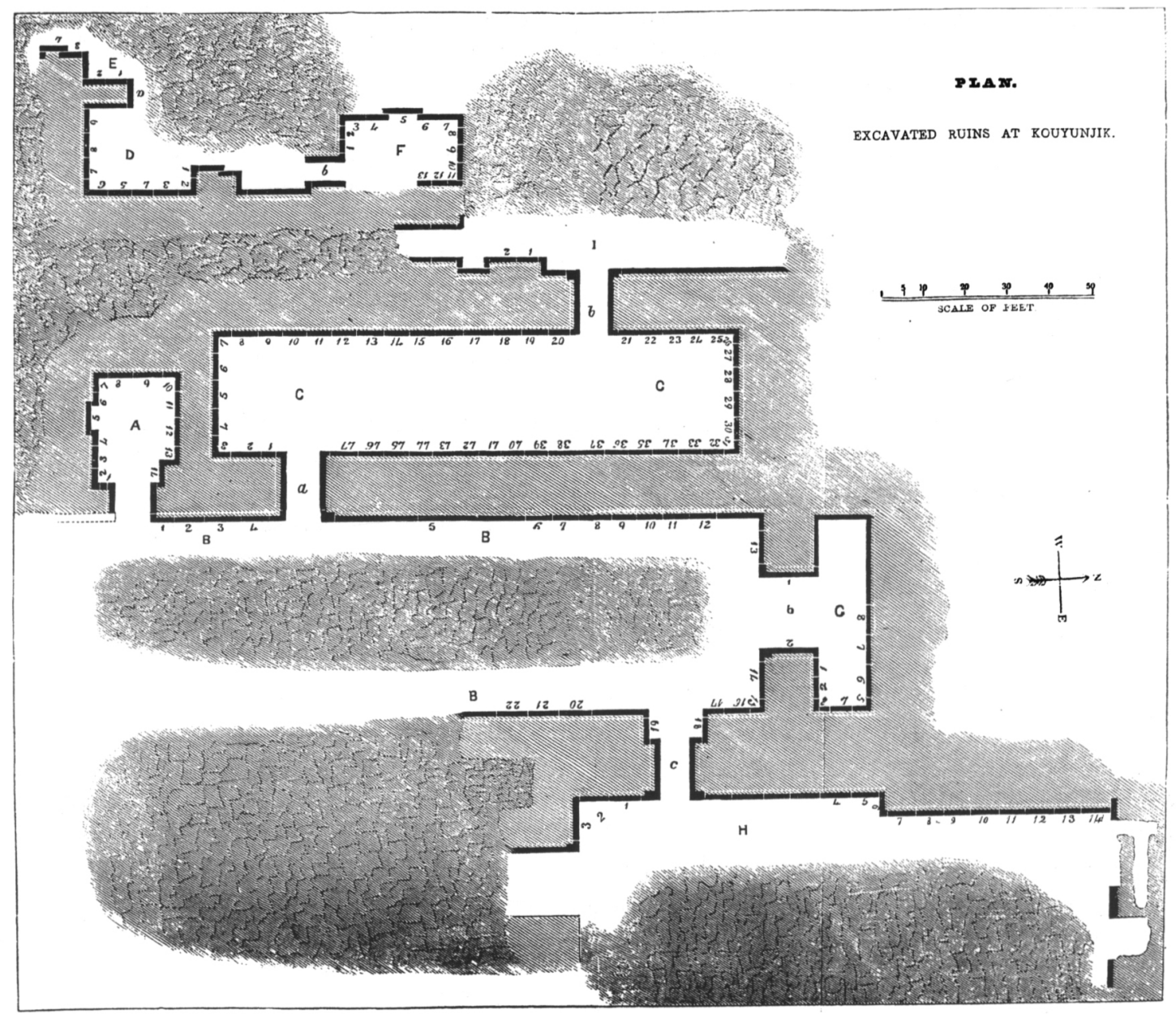

Fig. 1 Published plan of Layard's first campaign in the Southwest Palace, Nineveh (from Nineveh and Its Remains, vol. 2, opp. p. 124).

Layard's pocket notebooks, which are to be published in the British Museum catalogue of Sennacherib's palace reliefs.

BRITISH LIBRARY, ADD. MS. 39076

\section{Description of Plan of Excavations in Kouyunjik [fol. 43r]}

Chamber A [IV] Is in the edge of a ravine, which runs to a considerable distance into the mound and was the first part of the ruins discovered. The entrance $[f]$ was formed by two slabs upon each of which were two winged figures facing Chamber B. The first figure on each had the feet of an eagle, and was probably eagle-headed. The feet and lower part of the legs of these figures could alone be distinguished. All the slabs in the chamber were destroyed to within two or three feet of the bottom and were otherwise so much injured that drawings could not be made of what remained. Most of the slabs appeared to have been occupied by processions of warriors and captives, forests and mountains. On No. 11 could be distinguished part of a tripod, several vessels of various shapes, and (?) a censer. [fol. 44r]

Comment: Nineveh and Its Remains (vol. 2: 124-5) only mentions a single figure on the door jambs, though in fact there were two on each jamb.

Chamber B [I] The southern end of this chamber has been destroyed by the action which formed the 
ravine. As much as remains of No. 1, and part of No. 2 have been drawn. The remainder of No. 2 and the whole of No. 4 have been destroyed. No. 3 has been drawn.

Entrance $a[e]$ is formed by two gigantic human headed winged Bulls, the lower parts of which alone remain. Their length is about $16 \frac{1}{2}$ feet, and their height was probably about the same. They have but four legs - as the Bulls and Lions of the later palace of Nimroud. The inscriptions on both Bulls are too much destroyed to be copied. Between the Bulls a large slab of marble richly carved.

The whole of the slabs from Entrance $a$ to No. 6 have been almost completely destroyed. On No. 5 may be distinguished the feet of a gigantic figure. Of the remaining slabs part of No. 9 and No. 13 have alone been drawn. On the remainder appears to have been warriors ascending mountains covered with forests, as on Nos. 3 and 13, but the sculptures have suffered so much from fire that little can be distinguished.

No. 14 and part of No. 15 have been drawn - the upper part of No. 15 has been destroyed. The castle on No. 15 stands amongst mountains which rise from the seashore. A row of warriors discharging arrows on the lower part of the slab is all that is preserved of No. 16. Beneath these warriors, corresponding with each group, are legs from the knee - they may have belonged to figures which were subsequently erased. On the lower part of No. 17 is a row of prisoners and warriors.

No. 18 a row of prisoners at the bottom, above them warriors discharging their arrows. The rest of the slab occupied by mountains and pines. The figures are such as have been frequently drawn.

The wall from Entrance $c[c]$ to 20 destroyed.

No. 19 [crossed out] 20 has been drawn.

No. 20 [actually 21] Only a few figures on the bottom of this slab can be traced - they are warriors fighting. The rest of the slab has been entirely destroyed.

No. 21 [actually 22] - The whole slab destroyed - a few lines of inscription may be traced, but the characters cannot be copied. [fol. 44r-46r]

Comment: Nineveh and Its Remains (vol. 2: 125-30) describes the figure on Slab 5 only as "human", not "gigantic" - it is both of these. The extra set of legs on Slab 16 is not mentioned, though this detail is important because it identifies the original location of British Museum WA 124789. The subject of Slab 18 is published only as "battle", and 21 and 22 are not mentioned at all.

Chamber C [V] On No. 1 there appear to have been three lines of warriors one above the other. The lower are alone sufficiently well preserved to be drawn. No. 2 probably a continuation of the same subject, but the slab is so much injured that little can be distinguished. No. 3 three lines of warriors as on No. 1 - the two upper are slingers. One from No. 1 and two from No. 2 have been drawn. The rest are similar. No. 4 - the upper part of the slab destroyed - the lower part contains archers and warriors besieging a castle, but too much injured to be drawn. Nos. 5 and 6 are continuation of the same subject and have been drawn. Half of No. 7 has been drawn - the remainder contains lines of prisoners and warriors continued (without variety) from No. 6. No. 8 is much injured - it appears to have contained the King in his chariot preceded by warriors with the river and the usual mountain scenery, as in the previous slabs. Nos. 9 and 10 greatly injured - led horses, a castle and the usual mountain scenery can be distinguished. No. 11 is also much injured - the King in his chariot preceded by warriors can be traced. Above the King was an inscription, which is partly preserved. No. 12 almost entirely destroyed - warriors, trees mountains may be distinguished. No. 13 in the same state as previous - warriors driving prisoners and cattle may be traced. No. 14 has been partly drawn - beneath the castle etc. there is another row of prisoners and warriors but much injured. No. 15 a double row of prisoners can be traced. No. 16 under the mountains and trees is a row of warriors discharging arrows, with the shields (as in No. 37) - beneath a second line of warriors also discharging arrows but without the shields. Other warriors appear to be mounting to the assault of the city. No. 17 a castle on the summit of a hill - on the summit of the towers, which are defended by the enemy, are rows of circular bucklers. Some of the enemy appear to be falling from the castle walls. Warriors are climbing the hill, at the foot of which appears to be a town. Warriors have ascended the houses and are slaughtering the enemy. A sketch has been made of the castle, but this and the previous slab are too much injured to be drawn. No. 18 a double row of warriors with shields and bows - 


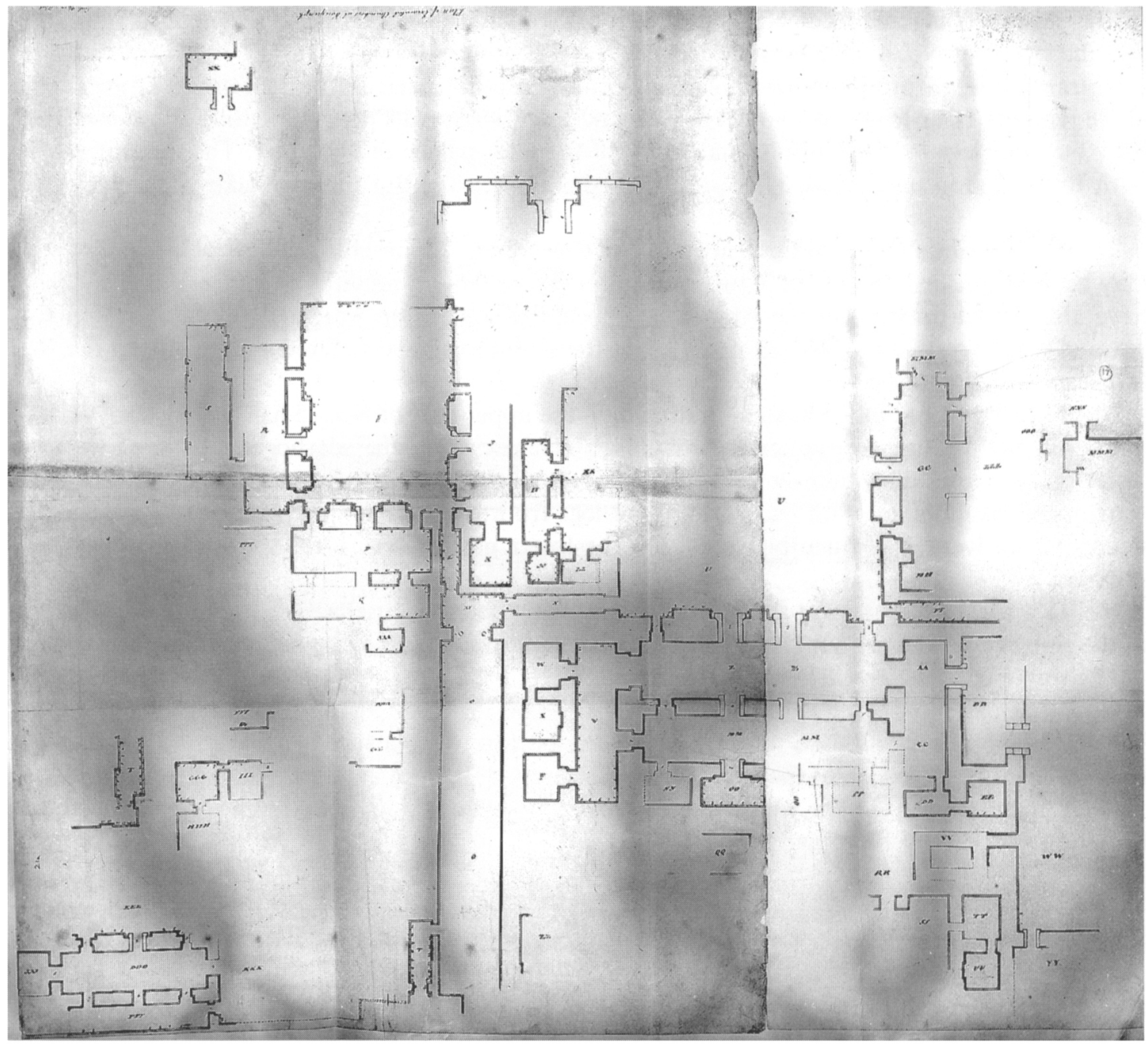

Fig. 2 Manuscript plan of Layard's second campaign in the Southwest Palace, Nineveh (British Museum, Western Asiatic Antiquities, departmental archives, folio volume labelled "Plans", No. 21, courtesy the Trustees of the British Museum).

the greater part of this slab is wanting. The remaining slabs of this side of the chamber are completely effaced. No. 27 a double line of warriors (facing 28) the first kneeling, with spears and shields, the second discharging arrows, and sheltered by the usual high shield. These warriors are separated by a river from horsemen ascending mountains (as in No. 30) - slab much injured - a fragment of a castle can be traced on the edge. No. 28 has been entirely destroyed and a well has been sunk in the place where it stood. It probably contained a castle, forming the sequel to No. 27 . No. 29 in the upper part of this slab were horses led by warriors - beneath them warriors bringing the heads of prisoners to scribes who are making a list - these are separated by a river from horsemen ascending mountains. No. 30 has been drawn. The whole of the wall from Nos. 31 to 47 , except such slabs as have been drawn, is in a very dilapidated state. The subjects of all the bas-reliefs, as far as they can be traced from fragments, were sieges of cities and battles in a mountainous country. Nos. 32, 35, 36, 37, 39 and 45 have been drawn.

In this chamber, at the foot of Slab No. 2, were found several of the small pieces of clay impressed with cuneiform inscriptions. [fol. 47r-49r]

Comment: The description of Slabs 9-14 is more detailed here than in Nineveh and Its Remains (vol. 2: 130-4), which in addition omits Slabs 15-18 entirely. The final list of six drawn slabs is more accurate than the published version, which reports that only four slabs were drawn. 
Chamber D [XLV] No. 1 without sculpture. No. 2 has been partly drawn - the remainder destroyed. No. 3 - a continuation of No. 4 - captives and warriors - but greatly injured. Nos. 4, 5 and part of 6 have been drawn. Of the remaining slabs only the lower part is preserved containing a line of horses led by warriors - a specimen of these has been sent to England - a fisherman in a pond, catching fish. [fol. 50r]

Comment: Only the slabs that were drawn are described in Nineveh and Its Remains (vol. 2: 135-6).

Chamber E [XLIII] What remains of Nos. 1 and 2 has been drawn. On the lower part of No. 3 may be distinguished a row of prisoners and warriors and a mule - ten figures in all. A mule carrying two women on No. 4 has been drawn; beneath are two archers followed by two female prisoners. On No. 5 is the lower part of a chariot, surrounded by water with fish. Behind the chariot is a horseman - beneath trees and mountains. All these slabs have been greatly injured and the upper part of them all is wanting. [fol. $51 \mathrm{r}$ ]

Comment: Only the slabs that were drawn are described in Nineveh and Its Remains (vol. 2: 136). The landscape information for Slab 5 is of particular interest, as none of the drawings shows any background detail at all.

Chamber F [XVII] Nos. 1 and 2 entirely destroyed - the lower part of these slabs remain, but the sculpture has suffered greatly - and drawings not made. No. 3 the King in his chariot - below warriors leading horses. No. 4 warriors bringing heads, scribes numbering the heads and other warriors following - beneath a procession of warriors. No. 5 two lines of warriors. No. 6 castle on a river. No. 7 archers and warriors besieging the castle. On No. 8 may be distinguished a led horse and three warriors following a chariot; beneath this group two other led horses - the slab in corner with trees and mountains. On No. 9 a led horse and three warriors - on No. 10 three warriors on No. 11 three women, prisoners. No. 12 entirely destroyed. No. 13 group of warriors, etc. discharging arrows, may be distinguished. A river runs at the bottom of all these slabs. [fol. 52r]

Comment: This room was only described briefly in Nineveh and Its Remains (vol. 2: 136) and the subjects of individual slabs were not listed.

Chamber G [III] The bas-reliefs in this chamber celebrate the conquest of a city in the midst of palm groves, and standing on the banks of a river. Unfortunately all the slabs are greatly injured - in the W part of the chamber so much so that they can scarcely be traced. Of Nos. 1, 2, and 3 the lower part alone remains - a river, and horses walking on its banks may be traced. On 2 and 3 may be distinguished horsemen and beneath them, at the bottom of the slab, a river. No. 4 has been drawn. No. 5 warriors and a river may be traced. On No. 5, preceding the King, three high-capped warriors with the shield, as in No. 4, and four archers. On No. 6 only a line of warriors can be traced. No. 7 the King in his chariot, two rows of warriors beneath - the slab has been too much injured to be drawn. No. 8 drawn. There are two lines of inscription on this slab - it is doubtful whether the lines were continued on No. 7 - no traces of characters remain on that slab. There is no mountain scenery in these bas-reliefs - the palm trees appear on every slab. [fol. 52v-53r]

Comment: This room was only described briefly in Nineveh and Its Remains (vol. 2: 137) and the subjects of individual slabs were not listed.

Chamber $\mathbf{H}$ [no Roman numeral] The bulls which form entrance $[c]$ are better preserved than those of the other entrances. The upper parts and heads being still nearly entire. The inscriptions have been copied.

Nos. 1 and 2 and the whole of the wall to the left of the Bulls have been purposely destroyed - at the bottom and edge of the slabs some traces of sculpture remain.

No. 3 a gigantic winged figure more than sixteen feet high - the head which was probably that of the divinity or genius with the horned cap, or that of an eagle - has been destroyed. The right hand, which probably held the fir cone, has also been destroyed - in the left is the usual basket.

Entrance $a$ [slab 12] is formed by two winged Bulls - the one adjoining No. 3 has fallen down the other has not been uncovered.

The lower parts of Nos. 4, 5 and 6 have warriors galloping and horses with warriors leading horses and with chariots beneath. The horses are executed with very great spirit. I have made a 


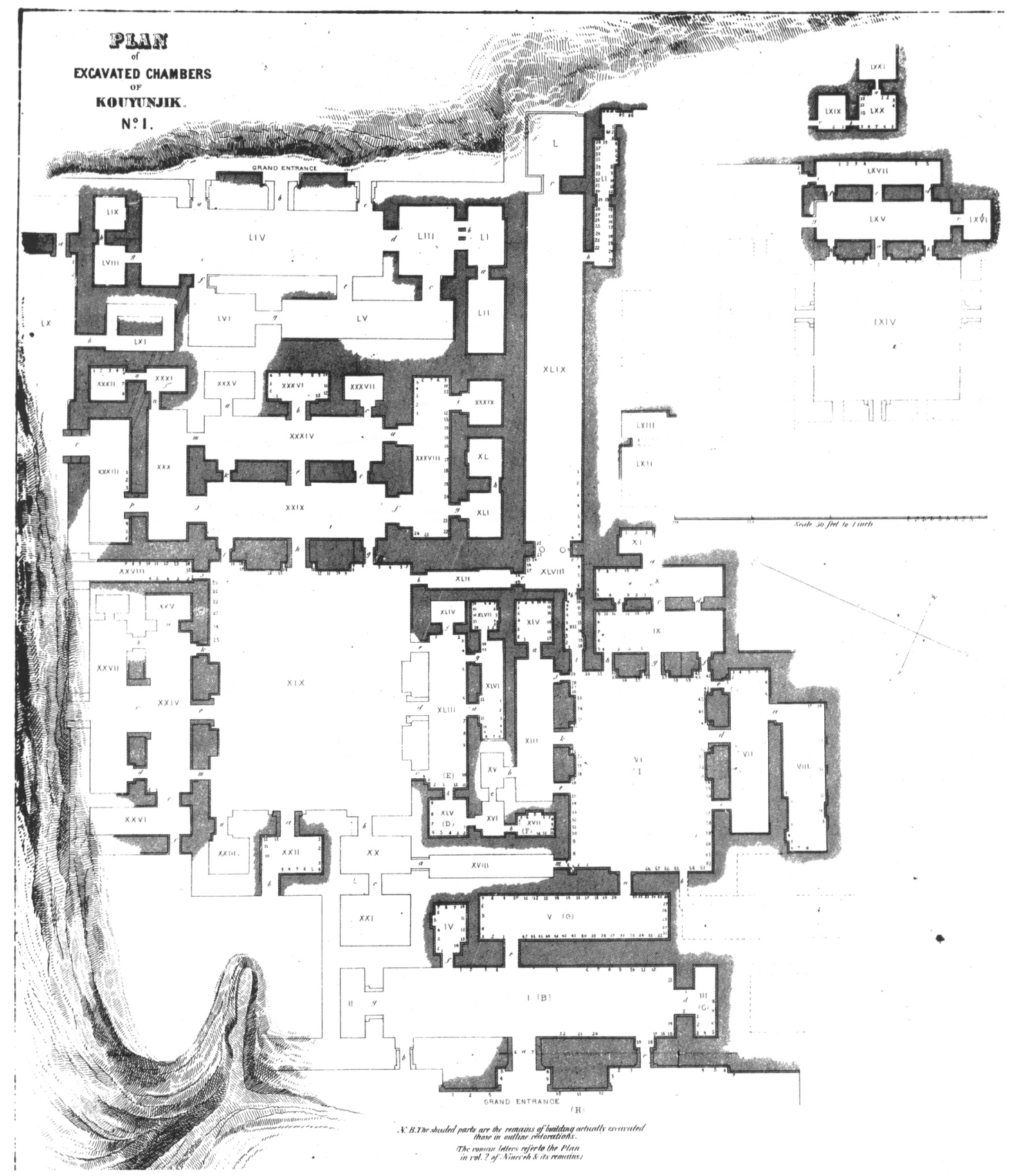

Fig. 3 Published final plan of Layard's excavations in the Southwest Palace, Nineveh (from Nineveh and Babylon, opp. p. 67).

plaster cast of the front [crossed out] best preserved. [fol. 53v-54r]

Comment: According to Nineveh and Its Remains (vol. 2: 130), the bulls in Door $a$ were "greatly injured". Neither Nineveh and Its Remains (vol. 2: 137-8) nor Nineveh and Babylon (p. 138) gives the height of the figure on Slab 3, nor do they mention Slabs 1 and 2.

Chamber I [VI] The entrance $[a]$ to this chamber is also formed by winged bulls -- the heads of which are wanting.

No. 1 has been drawn. No. 2 contains three lines of warriors, the first descending from the top of the slab, the two others proceeding corresponding [to] lines of previous slab - the warriors have the usual pointed caps. Underneath these are vines and trees but no pines - near river. A part of an 
inscription is on the slab - the rest was probably on No. 1 and the whole appears to have referred to the King.

All the remaining slabs appear to have been covered with lines of small figures extending from the top to the bottom of the slab - probably two or three hundred figures in all - being rows of warriors, warriors and prisoners and horsemen alternating. [fol. 55r]

Comment: Slab 2 is not described in Nineveh and Its Remains (vol. 2: 134-5) and the description of the subject of the "remaining slabs" - i.e. Slabs 8,9 , etc., on the south wall of Court VI - is fuller here as well.

BRITISH LIBRARY, ADD. MS. 39077

\section{Description of Excavations at Kouyunjik [fol. 75r]}

Great Hall or Chamber I [VI] The Eastern side of this hall from the entrance [a] to the SE corner was uncovered during the previous excavations, and the Bas-reliefs have been drawn. I have been unable to connect the narrow passage $[\mathrm{m}]$ at the SE corner, the walls of which are carved with rows of warriors, with the chambers to the south, owing to the dilapidated state of this part of the building. All the slabs and fragments which form the Southern side have been drawn. Between the Bulls forming the entrance $[k]$ was found a well which was excavated to about fifteen feet - it contained fragments of jars, and pieces of sculpture calcined and evidently fragments of the sculptured walls -all mixed with (apparently) human remains.

The eastern walls, to the North of the entrance $[a]$ formed by the bulls, contained the slabs representing the moving of the bulls and building of the mounds - which have been drawn. There is apparently an entrance $[b]$ where an intermission takes place in the slabs, as one of the adjoining slabs is sculptured on the side and that at the opposite side of the opening had been purposely defaced and no remains of sculpture could be traced upon it. Near this spot was discovered on the pavement the bas-relief representing a warrior on a rearing horse defending himself against an Assyrian spearman [British Museum WA 124773]. This sculpture does not, evidently, belong to this chamber being perfectly distinct in style and subject from the bas-reliefs forming the walls. The entrance described was excavated to a considerable depth and no remains of sculptured slabs found behind it.

Of the north wall from the NE corner to the first small entrance $[c]$ only fragments of the sculptures remain - scattered on the pavement. Enough was preserved to show that the bas-reliefs which occupied the wall represented the removal of bulls or of some such large objects in a hilly wooded country. Only fragments of the colossal figures which formed the small entrance $[c]$ were discovered. The slabs from this entrance to an angle in the wall have been drawn - they represent the removal of a bull. From this point to the great northern entrance [d] the slabs had fallen - from fragments on the pavement - some of which have been preserved and sent to England, they appear to have represented the removal of a bull near the banks of a river on which are rafts and men swimming on skins.

The upper part of the bulls forming the Northern Entrance [d] were completely destroyed. The lower part with the inscription was in fair preservation. The bulls were flanked on each side by two small figures, one above the other, one of which (the lower on the left facing the bulls) has been sent to England. The upper were completely destroyed. The slabs at the angles were winged figures, bearing the fir-cone and basket and facing the centre of the hall. The heads of both were wanting. The slabs from the great entrance to the next small entrance [e], representing the removal of a bull, upright, have been drawn. Near the great entrance was found the circular stone vessel surrounded by bas-reliefs of mythic groups.

The third entrance $[e]$ was formed by two colossal figures (not winged) holding a pole (probably surmounted by a pine cone). The upper part of these bas-reliefs was destroyed - the figures faced the great hall.

The slabs between this entrance and the first entrance $[f]$ on the western side had completely disappeared. The latter entrance was formed by four colossal figures - two on each side - one (the hinder) in each group representing the fish-god and only the lower part remained.

All the slabs of the western wall appear to have formed part of the subject represented on the 
southern side - the conquest by the Assyrians of a mountainous country. Such fragments as were sufficiently well preserved have been drawn. On the remainder could be distinguished mountains, trees, cattle and captives.

The bulls at the centre entrance $[g]$ were more injured than those at any other entrance in the building - and were broken into many fragments. Of the colossal figures forming the sides of this entrance, only the feet remained.

The next entrance $[h]$ was formed by four colossal figures, similar to those at the first small entrance $[f]$ on the same side. Only the feet of these figures remained.

The next entrance $[i]$, leading into a passage (L), had on each side three colossal figures, facing the great hall. The centre figure had the claws of an eagle attached to the legs of a man. The last figures carried a pole, probably surmounted by a pine cone. The upper part of all these figures completely destroyed.

The next entrance [ $j$ ], being in SW corner and leading to Chamber J, was formed by two colossal figures, one to each side, facing the great hall and by slabs of which fragments, representing lines of captives and Assyrian warriors in a mountainous country, only remain. [fol. 75r-76r]

Comment: The primary value of the manuscript account is that it gives a much fuller description of the decoration of individual doorways than does Nineveh and Babylon (pp. 69-71, 103-17). Layard's book does not give the subject of the slabs in Doors $b, f, h$, and $m$, nor does it give the find-spot of British Museum WA 124773 , which may originally have come from some room beyond Door $b$. Concerning Doors $c$ and $e$, Nineveh and Babylon (p. 229) reported that they were "guarded by colossal winged figures", but the manuscript account explicitly states that the figures in Door $e$ were not winged. The description of the decoration of Doors $d, g, i$, and $j$ here is much fuller than in Nineveh and Babylon (pp. 72, 73, 102, 229). Interestingly, his manuscript description of Door $d$ is identical to his published description of Door $k$ (p. 71). The manuscript also makes it clear that British Museum WA 124792, a wingless figure holding a standard, is from Door $b$, though Nineveh and Babylon (p. 71) seems to place it in Door $k$. It seems possible, therefore, that Layard confused Doors $k$ and $b$ in his published account. Layard's uncertainty in numbering Slabs 58 and 60 can easily be accounted for in light of his statement here that the slabs in this area were "scattered on the pavement" (see Russell 1991: 295 n. 45).

Chamber J [XIII] The walls of this chamber had been almost completely destroyed, and the chamber was not, consequently, all excavated. On the south side were found a few fragments representing warriors leading horses through a mountainous and wooded country, and others scaling the walls of a castle by ladders.

The entrance $[a]$ to Chamber $\mathrm{K}$ was sculptured on either side with two figures, facing the East, the lower parts of which alone remain. The first was probably an eagle-headed winged figure carrying the fir-cone and basket. The lower part of the second was formed by the hind quarters and claws of a lion. The upper part may have been that of a human figure or of a gryphon - it supported a pole. [fol. 76r]

Comment: Nineveh and Babylon (p. 72) does not mention the reliefs on the walls of this room, and the description of Door $a$ here is slightly more detailed.

Chamber K [XIV] All the slabs in this chamber have been drawn except those near the entrance $[a]$, which have been destroyed, the sculptures on that to the right having been purposely obliterated. [fol. 76r]

Comment: Cf. Nineveh and Babylon, pp. 72-3.

Chamber L [XII] The slabs on the north side have been drawn, except the last and the corner slab adjoining, on which was merely represented archers and slingers in a war, in a wooded mountainous country. The slabs on the East side and at the corners, not drawn, have only fragments of warriors and captives.

The entrance $[b]$ to the west is formed by sculptures having a continuation of the bas-reliefs in Chamber $\mathrm{M}$ - representing warriors walking on the banks on a river or lake - they are much injured.

The slabs forming the south side have been drawn. [fol. 76r]

Comment: Nineveh and Babylon (pp. 73-4) describes only the slabs that were drawn and makes no reference to Door $b$. 
Chamber M [XLVIII] The slabs forming this chamber have been drawn, except fragments on north side of which only the bottoms remain - they appear to have represented warriors and chariots passing through water and along the banks of a river or lake. The south entrance $[c]$ is formed by slabs representing warriors carrying off spoil - tables, couches etc., very indistinct - the south wall beyond continues the subject, and the slab on the west side, representing the King seated on his throne, within the walls of a city, to receive the captives and the spoil - has been drawn.

In the west entrance [unlabelled] were the circular pedestals which may have supported wooden pillars, or may have been altars. The slab on the south side of this entrance was almost completely destroyed - on it could only be distinguished a row of small trees, amongst which was the palm, probably representing a garden. That on the opposite side had been removed. [fol. 76r-76v]

Comment: Nineveh and Babylon (pp. 103, 119-20) describes only the slabs that were drawn and makes no reference to the decoration of Door $c$ or to the unlabelled door to Room $\mathrm{O}$.

Chamber N [XLII] The few remaining slabs in this entrance had been purposely defaced - on the west side of the chamber may be traced a few warriors on horseback, descending wooded mountains. The southern entrance $[b]$ is formed by two colossal figures, not winged, facing adjoining chamber. [fol. 76v]

Comment: Nineveh and Babylon (p. 342) does not describe the subject of these slabs, nor does it refer to Door $b$.

Chamber $\mathbf{O}$ [XLIX] The south side of this long gallery had been completely destroyed. The first slabs to the East on the North side, representing an obelisk or large stone in a boat drawn by men, have been drawn. Beyond these was found, in the fragments, the lion-headed figure in two pieces, sent to England, and several fragments representing the removal of Bulls or some such large objects and the King superintending. [fol. 76v]

Comment: Cf. Nineveh and Babylon, pp. 103-5.

Chamber P [IX] Very little remains of this chamber. On two fragments of slabs near the second west entrance $[c$ ?] are seen the King in his chariot, with his usual attendants, and warriors bringing the heads of the slain to the scribes. On some of these fragments are warriors in double file passing through a river, which runs through a mountainous country. The first entrance $[b$ ? ] on the west side completely destroyed. The second [c?] formed by two colossal figures facing East. [fol. 76v]

Comment: This is a more precise description than in Nineveh and Babylon (p. 228), which also omits mention of the doors.

Chamber $\mathbf{Q}[\mathrm{X}]$ Of the walls of this chamber only a few slabs were remaining. The two forming the SE corner are divided into two parts - the upper being occupied by warriors driving away camels, the lower by captive women and children and men kneeling before Assyrian warriors - in a mountainous country. The slabs at the SW corner representing an interior have been drawn. Adjoining them are lines of warriors leading horses. The slab adjoining the first entrance $[a]$, representing men carrying small figures, probably idols, on poles, has been drawn. The entrance has been completely destroyed. On the north side, a few fragments representing warriors - scribes receiving prisoners and cattle. [fol. 76v]

Comment: Only the slabs that were drawn are described in Nineveh and Babylon (pp. 228-9).

Chamber R [VII] A few fragments of slabs, representing chariots passing through water, on west side (drawn). On north side to entrance $[a]$ but mere fragments remaining - warriors on horseback and foot may be distinguished on the banks of a river amongst wooded hills. The only remaining slab, forming the NE corner, has been drawn. The east side completely gone - a passage extending to a considerable way opened from this side to the East but no remains of building except the pavement of a chamber discerned. The south side between the small entrance $[c]$ and the great entrance $[d]$ formed by the bulls has been drawn. The rest destroyed. [fol. 76v-77r]

Comment: Nineveh and Babylon (p. 229) gives only a general description, based on the drawings. The published plan omits the passageway at the east side of the room.

Chamber S [VIII] The entrance [a] from chamber R quite destroyed. On the south side but mere fragments remain, trees and mountains, until we reach the two slabs at the Eastern extremity, which 
have been drawn. The east side quite gone. Where the chamber narrows on the north side [Slab 10] there are the remains of two colossal figures facing west - the first facing being apparently lionheaded - like that sent to England - beyond a few fragments representing ships, warriors etc. have been drawn. On the west side were a few fragments representing rows of led horses amongst mountains near a river. [fol. 77r]

Comment: The description in Nineveh and Babylon (pp. 229-30) is based only on the drawings. Slab 10 is clearly identified here as a doorjamb, which confirms Turner's suggestion that "Room VIII" was actually two rooms (Turner 1970: 196, P1. 40 f; Russell 1991: 53).

$\mathbf{T}$ [LI north] A long passage - descending - on the right going down men bearing fruit, flowers, game, etc. - all drawn except the first which were destroyed, only the feet remaining. On these slabs were probably persons receiving the things brought - perhaps the King. On the left hand a row of led horses with the exception of Nos. 40 to 41 where the panelling of slabs is replaced by a solid wall of undressed stone. At Nos. 1 and 48 the wall ceases - the continuation has not been found although excavations have been carried on to a considerable distance. Sound slabs on both sides of the passage sent to England. The slabs at the entrance $[b]$ destroyed - on No. 40 one led horse on Nos. $41,42,43$ and 44 a footman preceded by two led horses. On Nos. 44 and 45 one led horse to 40 fourteen led horses. [fol. 77r]

Comment: Nineveh and Babylon (pp. 338-40) reports that the first slabs on the right (north) side were "entirely destroyed".

U [XIX] A great hall - nearly all the slabs on the West side have been drawn - those which are not are destroyed. Nos. 11 and 12 and some fragments have been sent to England. Entrance $1[\mathrm{~g}$ ] and probably 3 [ $i$, looks like " 2 " changed to " 3 "] formed of unsculptured limestone slabs. The bulls at Entrance 3 [actually "2", i.e. $h$ ] of highly fossiliferous limestone. Entrance $4[j]$ four colossal human figures facing hall. The two to the right have been drawn. Entrance $5[k]$ - four colossal human figures feet only remaining. Entrance $6[l]-$ Bulls - only hoofs remaining. Nos. 24 and 25 appear to have contained led horses, warriors, and continuation of the scene drawn, and warriors fighting. Beyond only fragments remain - a battle scene probably represented. [fol. 77r]

Comment: The description of Doors $g, i, j, k$, and $l$ are more complete here than in Nineveh and Babylon (pp. 230, 438-42, 445), which also does not mention Slabs 24 and 25.

V [XXXVIII] Most of the slabs in this chamber have been drawn. Those which have not are more or less imperfect and represent precisely the same subject - on a fragment (No. 17 or 18) was the

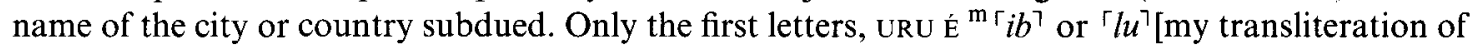
Layard's cuneiform copy] remain. Entrances to Chambers Y and W (3 [i] and $4[g]$ ) formed by fish-gods, one of which has been drawn, and by bas-reliefs continuing subject in respective chambers. The Entrance $2[d]$ formed by two colossal figures on each side facing south - the first figure probably entirely human and the second human with the hoofs of a bull. Only the lower part of the slab however remains. [fol. 77v]

Comment: The "letters" above the city are not identified in Nineveh and Babylon (pp. 342-3), nor is the subject of the inner jambs of Doors $g$ and $i$. The bull-legged human in Door $d$, which is not mentioned at all in the published account, was not reported elsewhere in Sennacherib's palace (Russell 1991: 313, n. 32).

W [XLI] All the slabs more or less destroyed. A few led horses could be distinguished and on the north side a sea or river covered with galleys and a castle on the shore. In this chamber was discovered the large collection of inscribed clay tablets. [fol. 77v]

Comment: It is not clear from Nineveh and Babylon (p. 344) whether this subject was in Room XL, or XLI, or both. The "led horses" are also not mentioned there, but are shown in an unlabelled lithograph that therefore must illustrate this room (facing p. 345).

$\mathbf{X}[\mathrm{XL}]$ All the slabs almost completely destroyed. Entrance $[h]$ into $\mathrm{W}$ formed by four colossal human figures - two on each side - the feet of which only remain. [fol. 77v]

Comment: The decoration of Door $h$ is not mentioned in Nineveh and Babylon (p. 344).

Y [XXXIX] On the west side a large interior of castle with tents and horses - persons occupied as in other similar representations - horses feeding, etc. The castle in a mountainous country wooded 
with high trees (?)firs. Without the castle archers and slingers. On the south side rows of chariots and horsemen. North and east sides gone. [fol. 77v]

Comment: The Assyrian fortified camp ("interior of castle") is not mentioned in Nineveh and Babylon (p. 347).

Z [XXIX] Long chamber a hall of unsculptured limestone blocks. The bulls at the great entrance and the slabs at the other entrances of similar material. [fol. 77v]

Comment: Cf. Nineveh and Babylon, p. 445.

AA [XXX] Chamber of similar unsculptured limestone slabs. [fol. 77v]

Comment: Cf. Nineveh and Babylon, p. 445.

BB [XXXIII] Entrance [p] from AA formed by two bulls in limestone. Six slabs only remaining three on each side of the entrance which have been drawn and sent to England. The rest completely destroyed and fragments removed for building a wall which crossed Chamber EE. The south side of this chamber is on the very edge of the mound. [fol. 77v]

Comment: Cf. Nineveh and Babylon, pp. 446-60.

CC $[\mathrm{XXX}]$ continuation of AA. [fol. 77v]

DD [XXXI] Entrance $[n]$ from CC four colossal figures facing CC - the first figure human, the second lion-headed - Similar to those at Entrance [o] to EE which have been drawn. No. 1 a large interior with tents, horses and animals as usual. No. 2 two rows of led horses, trees and mountains above and below. No. 3 the same. No. 4 upper row King in chariot with the usual guards and attendants - led horses in second row. No. 5 defaced. No. 6 two rows of prisoners - men, women and children - the hair of men as in Chamber EE - mountains and trees above - mountains, trees and river beneath. No. 7 similar rows of prisoners with bullocks. No. 8 siege of walls battering rams etc. - much injured. Nos. 9 and 10 archers, slingers etc. fighting against castle. No. 11 double row of chariots. [fol. 78r]

Comment: The decoration of this room is only briefly summarized in Nineveh and Babylon (p. 462).

EE [XXXII] All drawn except Nos. 4 and 5 on which are archers discharging arrows against castle and prisoners with sheep and cattle. [fol. 78r]

Comment: The subjects of Slabs 4 and 5 are not described elsewhere (Nineveh and Babylon, p. 462).

FF [XXVIII] All drawn except 13 and 14 - on which are led horses and warriors as on previous slab. [fol. 78r]

Comment: Cf. Nineveh and Babylon, pp. 442-4.

GG [XXIV] Between the entrance $[a]$ to HH and Entrance $5[k]$ lines of horses led by Assyrian warriors. Between this entrance and bulls $[l]$ city captured by Assyrians - warriors mounting ladders to assault - slingers, archers etc. Between bulls and Entrance $7[\mathrm{~m}]$ siege of city, battering rams etc. Beyond this entrance ships similar to those drawn. Slabs 1 and 2 interior of castle horses, mules and oxen feeding, sheep reposing - men making beds on ground, heaps of corn and the usual tents and implements - river running beneath the walls - adjoining slabs on $\mathrm{S}$ wall led horses - between Entrance $9[d]$ and $10[c]$ chariot of King, preceded by warriors - large size much injured but apparently of very fine execution. Entrance $8[e]$ two colossal figures facing Hall GG - first winged - second lion-legged. Entrance $9[d]$ - two figures facing Hall GG - the first a fish-god, the second lion-legged. The slabs adjoining, forming same entrance continue subject of walls in LLL - prisoners, women with children and Assyrian warriors. Entrance $10[c]$ lions with inscriptions much injured. [fol. 78r]

Comment: The description of the wall reliefs and Doors $c, d$, and $e$ is much fuller here than in Nineveh and Babylon (p. 442).

HH [XXV]. [Layard left this entry blank.] [fol. 78r]

Comment: Nineveh and Babylon (p. 442) reports that the reliefs in this room "had been almost entirely destroyed". 
II [XLVI] Most of the slabs remaining have been drawn. The rest were occupied by lines of carts, led horses, mules etc. as in drawings. The King in his chariot receiving the spoil was probably in the upper part of Slabs 4 and 5. Entrance $2[a]$ two figures faced KK - the first fish-god, the second lion-legged. Entrance $1[\mathrm{~g}]$ - slab adjoining II continuation of subject on walls. Next - lion-legged figure. [fol. 78r]

Comment: Doors $a$ and $g$ are not described in Nineveh and Babylon (pp. 583-4), and there is no mention of the king in his chariot.

JJ [XLVII] North side King in chariot. In the compartment above prisoners with carts, mules etc. as in II. On west side musicians with harps of peculiar form approaching King - mountainous wooded country. South side a line of prisoners leaving a castle captured by Assyrians on which inscription nearly destroyed - following letters of last line remain - $a q-\left\ulcorner q u r^{\urcorner}\right.$ina ${ }^{\mathrm{d}} \mathrm{GIŠs}^{\circ}{ }^{{ }_{\mathrm{BAR}}}{ }^{\urcorner} a q-$ $m u$ [my transliteration of Layard's cuneiform copy]. Entrance formed by two figures facing II. [fol. 78v]

Comment: The description here is more detailed than in Nineveh and Babylon (p. 584), and two additional broken signs are given at the beginning of the inscription fragment, the full text of which is in Russell 1991: 277. British Museum WA 124947, which shows musicians with harps, is evidently from Slab 8 or 9 . The inscribed slab (Russell 1991: Fig. 38) must be No. 10, 11, 12, or 13.

KK [XLIII] Slab 1 - carts with men, women and spoil preceded by archers as in those drawn. 2, 3, 4 drawn. 5 camel and captives as in 4 . All the slabs appear to have had lines of captives, carts etc. as in II. [fol. 78v]

Comment: Slabs 1 and 5 are not described in Nineveh and Babylon (pp. 582-4).

LL [XLIV] 1 led horses. 2 drawn - prisoners continue around NW corner. [fol. 78v]

Comment: Cf. Nineveh and Babylon, p. 583.

MM [XXXIV] Almost all the slabs in this chamber destroyed. Adjoining Entrance $4[l]$ an interior - with usual tents etc. and priest sacrificing sheep before a fire altar. Entrance 4 - Bulls in limestone. Entrance $8[b]$ - lions in same material. [What follows was added later above line and is very small and cramped from here to end of entry.] SE corner - castle on banks of river or sea ships with shields - lines of prisoners, women wearing [sketch of long headcloth] headdress - men [sketch of turban], mountains and trees behind castle. Entrance $6[\mathrm{~m}]$ - fish-god only[?] destroyed[?] [?] [?] facing CC. [fol. 78v]

Comment: The placement of the various subjects is not given in Nineveh and Babylon (p. 445), nor is Door $m$ mentioned. The figures in Door $b$ are there identified as bulls, but they seem in fact to have been lions, as indicated here and in the entry for Room $O O$.

NN [XXXVII] Slabs very much injured - Assyrian warriors, led horses and slingers could be distinguished. [fol. 78v]

Comment: The subject is not described in Nineveh and Babylon (p. 445).

OO [XXXVI] All drawn except south side and from SE corner to lion, on which apparently King in chariot receiving prisoners, and warriors leading horses. [fol. 78v]

Comment: The king in his chariot is not mentioned in the otherwise very full description of this series in Nineveh and Babylon (pp. 148-53).

PP [XXXV]. [Layard left this entry blank.] [fol. 78v]

Comment: Layard (Nineveh and Babylon, p. 445) reports that this room "had not been explored before my departure".

QQ [LV] Chamber surrounded by low slabs of very fine white limestone. [fol. 78v]

Comment: This room is not mentioned at all in Layard's published reports.

$\mathbf{R R}$ [LVI] Resembling former chamber - only partly excavated. [fol. 78v]

Comment: This room is not mentioned at all in Layard's published reports. 
SS [LIV, south end] Siege and capture of castle in mountains by Assyrians. Men and women, captives, leaving. Women wearing the high turban [sketch] and long drapes to feet. Northern entrance [unlabelled] apparently sculptured with mountains, trees etc. Opposite entrance $[g]$ destroyed. [fol. 78v]

Comment: This room and its door are not mentioned at all in Layard's published reports.

TT [LVIII] South side slabs much destroyed. A large castle in mountains surrounded by river. Assyrian warriors in possession of the walls and towers. Carts drawn by bullocks leaving castle. Rest of chamber destroyed. [fol. 78v]

Comment: This room and its door are not mentioned at all in Layard's published reports.

UU [LIX] Slabs almost destroyed - divided into compartments as in Chamber K. Lower line mountains - above these a river - then warriors, archers, slingers etc., led horses and mountains. Entrance $[h]--$ two figures facing TT - the second eagle-clawed. [fol. 78v-79r]

Comment: This room and its door are not mentioned at all in Layard's published reports.

VV [LXI] Inclined passage probably leading to upper chambers. Paved with lime about $1 \frac{1}{2}$ inch thick. Elevation of wall with projections [and] holes is drawn. Slabs at W extremity of passage, to left of entrance $[b]$ about $3 \frac{1}{2}$ feet high - of usual material. Impressions of seals found here. S entrance $[b]$ four figures facing WW - second eagle-clawed - the last fish-god. [fol. 79r]

Comment: The wall slabs to the left of the door are not mentioned in Nineveh and Babylon (pp. 153, 460-2).

WW [LX] On west side slabs destroyed - rivers and mountains only traceable. 1 and 2 castle on fire with inscription above - warriors passing through water, mountains and trees on either side. The trees below the water reversed. The rest of slabs on north side resemble those in Chamber $\mathrm{V}-$ much injured. [fol. 79r]

Comment: Nineveh and Babylon (p. 460) does not mention the slab numbers here, or that some of the trees were "reversed".

XX [XXII] This chamber must be connected with former excavations. The only sculptures in it have been drawn. Entrance [a] Lions. [fol. 79r]

Comment: Cf. Nineveh and Babylon, pp. 230-3.

YY [unnumbered room at extreme SW corner] Double rows of led horses and chariots finely executed. Chariot of King, warriors, palm trees. Entrance [a] formed by Bulls. [fol. 79r]

Comment: This room is not mentioned at all in Layard's published reports. Door $a$ is described in Nineveh and Babylon, p. 460 .

ZZ [LI south] Siege of castle, wariors etc. [fol. 79r]

Comment: Cf. Nineveh and Its Remains, vol. 2: 139-40, Nineveh and Babylon, 67-8.

AAA [XI] Lines of camels, prisoners, bullocks, mountains and trees divided into three bands. [fol. 79r]

Comment: This room is not mentioned at all in Layard's published reports.

BBB [LXII] and CCC [LXIII] low limestone slabs (about $3 \frac{1}{2}$ feet high) [fol. 79r]

Comment: Neither room is mentioned in Layard's published reports. The dado of (unsculptured?) limestone slabs is similar to examples reported by George Smith and R. C. Thompson in the same area (Russell 1991: 40-1, 44, 76-7).

DDD [LXV] A line of chariots in water between wooded mountains east side. Entrance $3[h]$ subject of adjoining slab continued and fish-god facing east. Between this Entrance and Entrance 2 [a] led horses - beyond (?)piles of wood burning, warriors bringing wood - castle on a river, mountains and trees. Entrance 2 Lions. NW corner an interior - line of figures bringing spoil to King seated on his throne. Entrance $7[d]-2$ figures facing East. Beyond, lines of figures bearing 
spoil - amongst it an umbrella - from castle in mountains. Entr. $6[e]$ - two figures facing East, the second lion-legged. [fol. 79r]

Comment: Nineveh and Babylon (p. 586) does not give the distribution of the slabs in this room, nor does it describe Doors $d$ and $e$.

EEE [LXIV] 1, 2, 3 and 4 drawn. 5, 6, 7 also drawn. Entrance 1 [b] Fish-god facing east. [fol. 79r]

Comment: Cf. Nineveh and Babylon, pp. 584-6.

FFF [LXVII] East side led horses, prisoners etc. North side almost entirely destroyed. West side led horses and interior (Nos. 5, 6). 1, 2, 3 drawn. The same subject continued on adjoining slabs. [fol. $79 r]$

Comment: Nineveh and Babylon (p. 586) does not mention the subject of the east wall or of Slabs 5 and 6.

GGG [LXX] 1, 2, 3, 4 drawn. 5, 6, 7, 8, 9 and adjoining slabs - long castle, with towers [and] walls occupied by Assyrian warriors. The King in his chariot followed by long line of warriors among palm trees. Compartment above a river and a besieged city. W and S sides long line of chariots. Entrance $2[a]$ continuation of subject and two figures facing West. [fol. 79r-79v]

Comment: The subject of Slabs 5 to 9 is not mentioned in Nineveh and Babylon (pp. 586-8).

HHH [LXXI] Walls almost entirely destroyed. [fol. 79v]

Comment: Cf. Nineveh and Babylon, p. 586.

III [LXIX] North side chariots, warriors and prisoners amongst palm trees. East side Assyrian warriors cutting down palm trees, castle, musicians etc. (to be drawn). South side lines of warriors divided into bands differently armed - the first with circular shields and crested helmets, the second archers, the third warriors with pointed helmets and convex shields, then chariots and led horses all amongst palm trees. Entrance $1[b]$ two figures facing north. Entrance $2[c]$ two figures facing south, the second eagle-clawed. [fol. 79v]

Comment: The north and south walls are not described in Nineveh and Babylon (p. 588), nor is Door $c$.

JJJ [LXVI] Entrance $[c]$ two figures facing south - first winged figure with basket - second lionlegged - both almost destroyed. Led horses amongst vines to be distinguished. Beyond this chamber the surface of the mound is almost on a level with the flooring. [fol. 79v]

Comment: Nineveh and Babylon (p. 586) does not give the subject of the reliefs on the walls or in the door.

KKK [unnumbered room to south of LXV/LXVII, possibly LXVIII] 1, 2, 3 to be drawn. Siege of city on mountain, horseman leading away a captive by the hair. Entrance $1[i]$ part mountains and trees - rest lion-legged figures facing north. Entrance $4[g]$ two figures facing north - second figure lion-legged, the first winged with basket. [fol. 79v]

Comment: This room and its doors are not mentioned in Layard's published reports.

LLL $[\mathrm{XXVII}]$ Between Entrances $9[d]$ and $10[c]$ warriors bringing heads and leading captives by the beard. Beneath them river and mountains with trees. Entrance 9 two figures facing west - first winged figure, second lion-legged. Entrance 10 Lions. [fol. 79v]

Comment: The description of the relief subject is fuller here than in Nineveh and Babylon (p. 442). According to Nineveh and Babylon and the description of Room GG above, the first figure in Door $c$ was a fish-god.

MMM [XXVI] North side led horses, prisoners etc. East side siege of city. [fol. 79v]

Comment: Nineveh and Babylon (p. 442) does not report the subject of these reliefs.

NNN [unnumbered space to east of XXVI] destroyed. [fol. 79v]

Comment: This room is not mentioned at all in Layard's published reports.

OOO [XXIII] Entrance $2[n$ ] figures facing west — second fish-god. [fol. 79v]

Comment: This room and its door are not mentioned in Layard's published reports. 
CONCORDANCE OF ROOM NUMBERS AND LETTERS

\begin{tabular}{llllll}
\hline I & B & XXV & HH & XLIX & O \\
II & none & XXVI & MMM & L & none \\
III & G & XXVII & LLL & LI north & T \\
IV & A & XXVIII & FF & LI south & ZZ \\
V & C & XXIX & Z & LII & none \\
VI & I & XXX & AA, CC & LIII & none \\
VII & R & XXXI & DD & LIV & none \\
VIII & S & XXXII & EE & LV & QQ \\
IX & P & XXXIII & BB & LVI & RR \\
X & Q & XXXIV & MM & LVII & SS \\
XI & AAA & XXXV & PP & LVIII & TT \\
XII & L & XXXVI & OO & LIX & UU \\
XIII & J & XXXVII & NN & LX & WW \\
XIV & K & XXXVIII & V & LXI & VV \\
XV & none & XXXIX & Y & LXII & BBB \\
XVI & none & XL & X & LXIII & CCC \\
XVII & F & XLI & W & LXIV & EEE \\
XVIII & none & XLII & N & LXV & DDD \\
XIX & U & XLIII & E, KK & LXVI & JJJ \\
XX & none & XLIV & LL & LXVII & FFF \\
XXI & none & XLV & D & [LXVIII] & KKK \\
XXII & XX & XLVI & II & LXIX & III \\
XXIII & OOO & XLVII & JJ & LXX & GGG \\
XXIV & GG & XLVIII & M & LXXI & HHH \\
\hline
\end{tabular}

Bibliography

Layard, Austen Henry, Nineveh and Its Remains, 2 vols., London: John Murray, 1849.

Layard, Austen Henry, Discoveries in the Ruins of Nineveh and Babylon, London: John Murray, 1853.

Russell, John Malcolm, Sennacherib's Palace Without Rival at Nineveh, Chicago: University of Chicago Press, 1991.

Turner, Geoffrey, "The State Apartments of Late Assyrian Palaces", Iraq 32, 1970, pp. 177-213. 